\title{
Criterion and Others
}

\author{
By Jan Uhde
}

Spring 2009 Issue of KINEMA

THE DVD MEDIUM, born a decade ago, has by now considerably broadened its content range to what one could only dream about just a few years ago. Masterpieces of world cinema new and old, movies forgotten, prohibited, censored, damaged or presumed lost, are now available on the small inexpensive silver discs in increasing quantities. Among the growing numbers of DVD publishers, some have earned worldwide reputation for the choice of content and superior technical quality of their output. The most noticeable among them is the Criterion Collection which has been distributing films of exceptional quality since 1984 . By early 2009, Criterion had published over 460 outstanding DVD titles. Other companies fuelled by similar ambition have joined their ranks. Their discs have significantly contributed to the DVD revolution. The following are just a few examples of the recent output of remarkable titles.

After the resounding success of the Anthology of Polish Animation DVD, (1958-2007), the Polish audiovisual publishers brought out two more animated collections: the Anthology of Polish Animation for Children of the last 60 years (3-disc set, $360 \mathrm{~min}$ ) and monumental collection of Polish experimental animation. Forty shorts produced between 1944-2007 made by the country's finest animators, including Jan Lenica, Walerian Borowczyk, Zbigniew Rybczyski, Józef Piwkowski, Piotr Szulkin, Mariusz Wilczyski, and Tomek Sikora make up this set from one of the world's most vibrant animation sources.

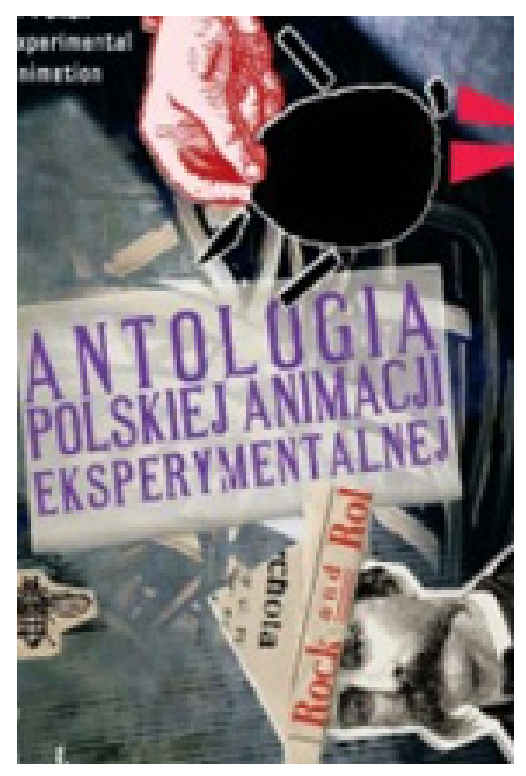

Figure 1: ANTHOLOGY OF POLISH EXPERIMENTAL ANIMATION DVD ฯ (3-disc set, various directors, 1944-2007), PAL, R-2, 259min. Booklet. Polish w/English Subtitles. ๆ Polskie Wydawnictwo Audiowizualne.(USD 14.50-25.00).

Abel Gance's masterpiece of the film impressionism featuring the characteristic rapid-montage which preceded his famous Napoléon, was now restored from scattered sources to its original epic length at Lobster Film Studios in Paris and published by Flicker Alley, a Californian company started in 2002 by film enthusiast Jeffery Masino. It is scored by award-wining American composer Robert Israel who wrote music for almost 100 silent movies. The DVD inclu des a making of documentary and a 16-page booklet with an essay by William N. Drew on the history and influence of La roue. Flicker Alley, named after London's Cecil Court, the business centre of the British film industry during the silent era, also published Abel Gance's antiwar J'accuse (I Accuse, 1919) and numerous other classics. 


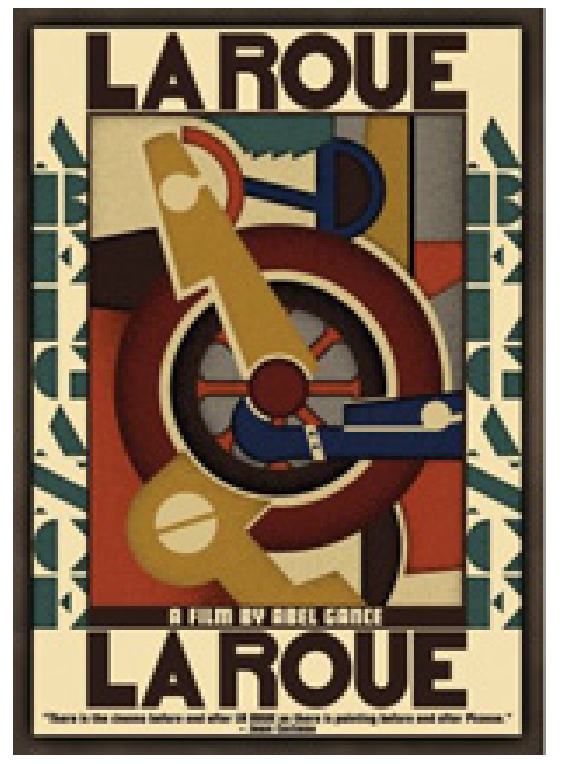

Figure 2: LA ROUE \ (The Wheel, France 1923, 270 min, 2-discs, NTSC R-0)

The first animation feature, Lotte Reiniger's famous 1926 silhouette film The Adventures of Prince Achmed (Die Abenteuer des Prinzen Achmed) issued on DVD in 2001 (BFI Studio, Region 2) and 2002 (Image Entertainment, Region 1), now has a worthy companion. Lotte Reiniger - The Fairy Tale Films is a twodisc set containing nineteen shorts by the director produced between 1922 and 1961. Reiniger's 1922 silent Cinderella, her 1953 Aladdin and the Magic Lamp, and Grasshopper and the Ant (1954) are included in this massive collection which contains half of the filmmaker's lifetime production.

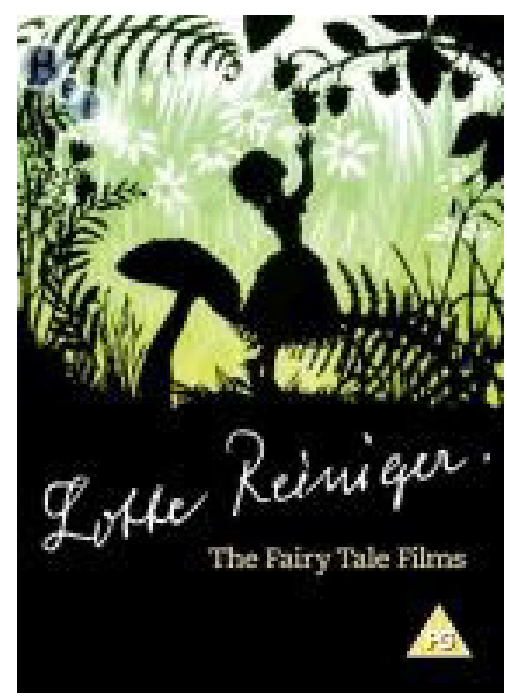

Figure 3: LOTTE REINIGER - THE FAIRY TALE FILMS \ (2-disc set, BFI Studio 2008, 197min). ๆ $18 \mathrm{~min}$ extras and a page booklet. PAL, R-2. 


\section{Author Information}

Jan UHDE is Professor Emer. (Film Studies) at the University of Waterloo, Ontario, Canada. Born in Brno, Czech Republic. Graduated (MA) from the Faculty of Arts, Masaryk University, Brno; PhD received at the University of Waterloo, Ontario, Canada. He taught at the University of Waterloo (1970-2012) where he founded a General and Honours BA program in Film Studies at the Department of Fine Arts.

Publications: Latent Images: Film in Singapore Second edition, with Yvonne Ng Uhde (Ridge Books, National University Press of Singapore, 2010); Latent Images: Film in Singapore, with Yvonne Ng Uhde (Oxford University Press, 2000); Latent Images: Film in Singapore CD-ROM (2003, co-author); Vision and Persistence: Twenty Years of the Ontario Film Institute (University of Waterloo Press, 1990) and Ontario Film Institute Programming Activities Index 1969-1989 (Toronto: Ontario Science Centre, 1990). He co-edited the Place in Space: Human Culture in Landscape (Proceedings from the Second International Conference of the Working Group "Culture and Landscape" of the International Association of Landscape Ecology, Pudoc Scientific Publishers, Wageningen, Holland, 1993). Jan Uhde has published articles and reviews in several countries (including Canada, USA, Germany, Italy), participated in international juries at film festivals and presented papers at international conferences in North America and Europe. In 1998/99, he was a visiting researcher at the School for Film and Media Studies, Ngee Ann Polytechnic, Singapore.

His professional and research interests focus on Singapore cinema; the identification and distancing mechanisms of the film viewer; the non-authored modifications and manipulation of films; and specific aspects of film history, including the Central European cinema.

He founded KINEMA in 1993. 